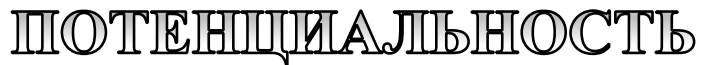

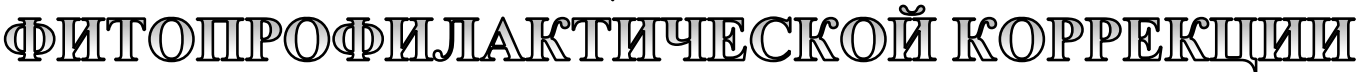

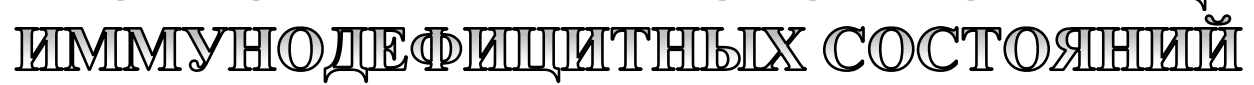

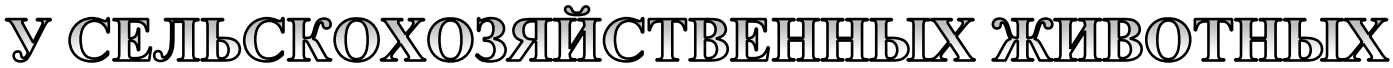

И.Н. Жданова, Пермский научно-исследовательский институт сельского хозяйства

Е.В. Суханова, Пермский научно-исследовательский институт сельского хозяйства

Для цитирования:

Жданова И.Н., Суханова Е.В. Потенциальность фитопрофиилактической коррекции иммунодефицитных состояний у сельскохозяйственных животных // Вестник Пермского федерального исследовательского центра. - 2021. № 4. - C. 31-36. https://doi.org/10.7242/2658-705X/2021.4.3

Представлены результаты скармливания витаминно-травяной муки из левзеи сафллоровидной, эспарцета песчаного и клевера лугового крупному рогатому скоту молочного направления с целью улучшения обменных процессов в организме и репродуктивной функции коров. Зоотехническая и ветеринарная науки предусматривают осуществление и разработку прогрессивных современных технологий производства животноводческих продуктов и сырья. В свете проводимой государственной политики импортозамещения особую актуальность приобрела необходимость повышения внутреннего производства критических позиций продуктов питания, среди которых особую роль играет коровье молоко и мясо говядины.

Для обеспечения устойчивого роста поголовья и продуктивности крупного рогатого скота необходимо наличие здорового чистопородного молодняка. За период 2016-2020 гг. в Пермском крае на основе формы 2-вет в животноводческих хозяйствах всех категорий у крупного рогатого скота в 42-44\% случаев регистрировалась патология со стороны пищеварительной системы неинфекционной патологии, в том числе от количества заболевших - у молодняка в $76,7 \%$ случаев. Анализ заболеваемости крупного рогатого скота болезнями органов дыхания в Пермском крае показал, что респираторные болезни телят широко распространены (25-31\% от числа всего заболевших незаразными болезнями). Данная патология протекает тяжело в возрасте перехода на групповое содержание животных. Несмотря на накопленный в последние десятилетия обширный арсенал иммуномодуляторов природного и синтетического происхождения, до сих пор актуальным остаётся вопрос изыскания и использования наиболее активных, экологически безопасных средств.

В условиях современного молочного животноводства большое распространение получило использование различных кормовых добавок, премиксов, пробиотических препаратов, в том числе и сухого растительного сырья в качестве витаминно-травяной муки, обеспечивающих высокий уровень продуктивности, снижение затрат обменной энергии на единицу 
продукции и сохранность молодняка животных. Результаты исследований могут быть использованы в селекции многолетних трав, в отраслях семеноводства и кормопроизводства, при кормлении животных в хозяйствах любых фрорм собственности.

Ключевые слова: лекарственные растения, биологически активные вещества, вторичные иммунодефициты, крупный рогатый скот, иммуномодуляторы, ветеринарная фитофармакология, сельское хозяйство.

Опыт применения лекарственных растений для профилактики и лечения заболеваний исчисляется тысячелетиями, и уже это прямо и косвенно свидетельствует об их эффективности. Но самым большим плюсом фитопрофилактики, пожалуй, является минимальный побочный эффект даже при длительном применении лекарственных растений, особенно у хронических пациентов.

Безусловно, лекарственные растения не могут в полной мере соперничать с синтетическими средствами по силе и быстроте эффекта. Однако дозу последних часто удается снизить при одновременном применении их с фитопрепаратами. Кроме того, подкупает относительная дешевизна, доступность лекарственных растений и возможность самому собрать сырье и приготовить лекарство. Многие фитопрепараты можно применять при беременности и лактации и, что очень важно, - для профилактического лечения и предупреждения рецидивов ряда хронических заболеваний. Несмотря на накопленный в последние десятилетия обширный арсенал растений, обладающих иммуномодулирующим действием, до сих пор актуальным остаётся вопрос изыскания и использования наиболее активных, экологически безопасных средств.

Современное сельское хозяйство Пермского края развивается на промышленной основе. Вместе с тем на животноводческих комплексах происходит сосредоточение на малых площадях больших количеств животных, частая их перегруппировка по возрасту, продуктивности и другим показателям, ограничиваются возможности свободного движения, исключается облучение солнечными лучами, исчезает возможность выбора кормов и др. Специфика сложившегося технологического цикла получения и выращивания молодняка, многочисленные стрессогенные факторы, неадекватные условия содержания, кормления, а также постоянное воздействие вирусных возбудителей препятствуют полноценному развитию иммунитета и приводят к формированию вторичных иммунодефицитных состояний. Такие состояния приводят к хроническому дисбалансу питательных веществ (дефицит поступления и всасывания белков, витаминов и минералов) и токсичных продуктов метаболизма. Поэтому в настоящее время с целью повышения экономической эффективности отрасли животноводства Пермского края большой интерес представляет использование в качестве кормовых и биологически активных добавок фитокомплексов, состоящих из основных биологически активных веществ (БАВ).

Анализ опубликованных источников показывает, что в последнее время у целого ряда различных растений обнаружены вещества, обладающие широким спектром действия на организм животных и человека, способные повысить адаптационные возможности организма к условиям окружающей среды, укрепить естественную резистентность и иммунологическую реактивность. В первую очередь к таким веществам относятся фитоэкдистероиды, флавоноиды, витамины и другие метаболиты растений. В этой связи заслуживает внимания комплекс биологически активных веществ (БАВ) растений-адаптогенов, обладающих анаболическим и антистрессовым эффектом с антиоксидантными свойствами. 
В лаборатории биологически активных кормов Пермского НИИСХ с 1969 г. ведется изучение коллекции сортов кормовых растений, в том числе образцов из дикой флоры (левзея сафлоровидная, эспарцет песчаный, клевер луговой и астрагал нутовый и др.), обладающих хозяйственно-ценными признаками, а также содержащих необходимые БАВ для повышения иммунного статуса и увеличения реализации генетически заложенного потенциала продуктивности у сельскохозяйственных животных, в частности крупного рогатого скота. Преимуществом выращиваемых нами растений, обладающих адаптогенными свойствами, является возможность их применения без предварительного иммунологического обследования животных. Эти растения способствуют нормализации иммунного статуса.

Рапонтик сафлоровидный (левзея, маралий корень) и препараты, изготовленные на его основе, используются в качестве стимулирующего средства. Левзея относится к ценным кормовым и лекарственным растениям. Преимущество этой культуры в кормопроизводстве заключается не только в раннем получении зелёной массы и её кормовых качествах, но и в иммуномодулирующих свойствах, положительно влияющих на обменные процессы в организме, а также на продуктивные и воспроизводительные функции животных.

Эспариет песчаный отличается длительным сроком эксплуатации (8-9 лет), высокой урожайностью: в зависимости от региона возделывания урожайность зеленой массы культуры варьируется от 120 до 400-500 ц/га; холодо- и морозостойкостью, что немаловажно для Пермского края. Продуктивность эспарцета песчаного сочетается с его высокой питательностью, так как эспарцет содержит высокое количество сахара, которое обеспечивает хорошие поедаемость и переваримость питательных веществ сельскохозяйственными животными.

В 1 кг сена из эспарцета содержится 11 г Са, который необходим для построения костяка у молодняка сельскохозяйст- венных животных, а также 2,5 г фосфора. Высокое содержание витамина С в листьях эспарцета песчаного способствует укреплению иммунитета, благоприятно действует на центральную нервную систему и обмен веществ. Аминокислоты, содержащиеся в растении, помогают восстановлению организма после перенесенных заболеваний.

Астрагал - многолетнее растение семейства бобовых (Fabaseae) известно в восточной медицине более 2000 лет. Однако фундаментальных исследований биохимического состава, кормовых и фармакологических свойств нет. Считается, что астрагал обладает более значительными лечебными свойствами, чем женьшень. Астрагал восстанавливает и стимулирует иммунные функции клеток организмов животных и человека. Растение содержит различные органические кислоты, включая аскорбиновую, которая стимулирует иммунную систему человека. А также витамины группы В, полисахариды [1-7].

Ранее проведённые нами исследования показали, что травы: левзея сафлоровидная ( $R$. carthamoides), эспарцет песчаный (O. arenari), клевер луговой (T. praténse) содержат протеин, сахара, витамины, аминокислоты, дубильные вещества и флавоноиды. Анализ биохимического состава и сумму экдистероидов и флавоноидов в наземных частях левзеи сафлоровидной и эспарцета песчаного проводили в аналитической лаборатории Пермского НИИСХ и на кафедре физиологии растений ПГНИУ.

Витаминная травяная мука - это натуральный белково-витаминный корм для сельскохозяйственных животных или добавка при производстве полнорационных комбикормов, полученные из искусственно высушенных многолетних бобовых или бобово-злаковых трав. По питательности она приближена к концентратам и не уступает традиционным зерновым кормам, а по содержанию БАВ превосходит их. В одном килограмме витаминной травяной муки содержатся более 200 г перевариваемого протеина, до 300 мг каротина и почти все незаменимые аминокислоты. 
Витаминная травяная мука применяется в рационах птиц, коров, свиней, коз, лошадей, кроликов и других животных. По количеству протеина витаминно-травяная мука значительно превосходит не только сено, сенаж, силос, но и большинство зерновых культур. Использование витаминно-травяной муки из вышеперечисленного растительного сырья в рационе высокопродуктивных животных, с одной стороны, обеспечивает увеличение количества и качества биологических продуктов, а с другой - активизирует механизмы их безопасности. Она совместима с другими кормовыми добавками и не содержит вредных для человека и животных компонентов.

Использование витаминно-травяной муки в наших экспериментах направлено, в первую очередь, на повышение иммунорезистентности, увеличение реализации генетически заложенного потенциала продуктивности у крупного рогатого скота и улучшение микробиологического баланса желудочно-кишечного тракта. Трава культурных пастбищ является одним из самых полноценных и дешёвых кормов для крупного рогатого скота. С физиологической точки зрения зелёная масса полностью соответствует потребностям коровы.

Лабораторией биологически активных кормов Пермского НИИСХ в 20172020 гг. были проведены научно-производственные опыты по скармливанию витаминно-травяной муки из зелёной массы левзеи сафлоровидной, эспарцета песчаного и клевера лугового молодняку и лактирующим коровам на крупных молочных животноводческих предприятиях Пермского края.

По результатам исследований разработана система рационального кормления крупного рогатого скота на кормах местного производства с добавлением растительного сырья, обладающего повышенным иммуностимулирующим действием.

В результате скармливания ВТМ из зелёной массы левзеи сафлоровидной в период с 31 по 81 день выращивания тё- лочек крупного рогатого скота создаются более благоприятные условия для жизнедеятельности рубцового пищеварения, что способствовало большей переваримости сухого и органического вещества в организме у подопытных животных, по сравнению с традиционным кормлением. Количество общего белка и белковых фракций в крови подопытных животных также превысило исходные значения в начале эксперимента на 20\% соответственно. Прирост живой массы животных опытных групп составлял на 9-10\% выше, чем в контрольной.

Получены экспериментальные данные о влиянии скармливания ВТМ из зелёной массы эспарцета песчаного на обменные процессы в организме беременных животных и репродуктивную функцию коров после родов.

Исследования проводились на коровах чёрно-пёстрой голштинизированной породы первой и второй лактации в период с 21 дня до и 50 дней после родов. У коров опытных групп были существенно выше коэффициенты переваримости: сухого вещества, органического вещества, сырого протеина, сырого жира, сырой клетчатки выше по сравнению с коровами контрольной группы, соответственно; появление первого полового цикла после отёла у коров контрольной группы по сравнению с коровами опытных групп наступило позже; оплодотворяемость коров от первого осеменения составила в контрольной группе $10 \%$, в первой опытной $-20 \%$, во 2-й опытной $-40 \%$; в учётный период научно-производственного опыта (за 120 дней лактации) от коров опытных групп получено молока больше по сравнению с коровами контрольной группы. Проведенный расчёт эффективности показал, что сумма выручки от реализации молока была в опытных группах выше, чем в контрольной.

В 2020 году были проведены исследования по скармливанию клевера лугового половозрастным коровам крупного рогатого скота. В ходе эксперимента были получены следующие данные: у животных опытных групп суточный выход молочного 
жира и белка выше на 4,61-10,32\%, по сравнению с контрольной группой, гематологические и биохимические результаты исследования крови соответствовали физиологическим нормам, оплодотворяемость коров от первого осеменения составила в контрольной группе $10 \%$, в первой опытной $-20 \%$, во второй опытной $-40 \%$.

В 2021 году нами поставлена цель в кормлении молодняка крупного рогатого скота и сельскохозяйственной птицы применять в основном рационе в качестве биологически активной добавки витаминно-травяную муку из астрагала нутового и левзеи сафлоровидной.

В настоящее время фитопрофилактику необходимо все более активно интегрировать в практическую ветеринарную медицину для повышения качества схем профилактики и лечения различных иммунодефицитных состояний сельскохозяйственных животных. Она существенно расширит кругозор и возможности зооветеринарных служб при использовании на животноводческих предприятиях для профилактики и лечения, а также для оздоровления всего поголовья сельскохозяйственных животных.

Проведённые испытания формируют новые знания о росте и развитии, кормовой и семенной продуктивности традиционных и новых видов и сортов многолетних кормовых трав, в том числе образцов из естественной флоры Пермского края. Накапливается экспериментальная информация по использованию в животноводстве травянистых кормов, обладающих повышенной биологической активностью для коррекции иммунной системы сельскохозяйственных животных.

\section{Библиографический список}

1. Волошин B.A. Предварительные итоги изучения эспарцета песчаного в Пермском крае // Сибирский вестник сельскохозяйственной науки. - 2015. - № 1. - С. 49-55.

2. Волошин В.А., Матолинеи Д.А., Морозков Н.А., Майсак Г.П. Роль левзеи сафлоровидной в кормлении молочных коров // Сибирский вестник сельскохозяйственной науки. - Т. 49. - 2019. № 5. - С. 52-60.

3. Жданова И.Н. Морфобиохимические показатели крови и молочная продуктивность у коров при скармливании витаминно-травяной муки из эспарцета песчаного // Аграрная наука. 2021. - № 3. - С. 56-60.

4. Матолинец Д.А., Волошин В.А. Биологические особенности и элементы технологии возделывания левзеи сафлоровидной в условиях Пермского края // Кормопроизводство. 2018. - № 1. - С. 21-25.

5. Овсянников А.И. Основы опытного дела. - М.: «Колос», 1976. - 304 с.

6. Суханова E.B. Применение витаминно-травяной муки из эспарцета песчаного для повышения продуктивности лактирующих коров и сохранности телят молочного периода в условиях Пермского края // Известия Оренбургского аграрного университета. - 2020. - № 6. - С. 291-294.

7. Miliauskas G., van Beek T.A., de Waard P., Venskutonis R.P., Sudholter E.J. Identification of radical scavenging compounds in Rhaponticum carthamoides by means of LC-DAD-SPENMR. J Nat Prod. 2005. - Vol. 68. - Is. 2. - P. 168-172. 


\title{
THE POTENTIALITY OF PHYTOPROPHYLACTIC CORRECTION OF IMMUNODEFICIENCY CONDITIONS IN AGRICULTURAL ANIMALS
}

\author{
I.N. Zhdanova, E.V. Sukhanova \\ Perm Scientific Research Institute of Agriculture
}

\section{For citation:}

Zhdanova I.N., Sukhanova E.V. The potentiality of phytoprophylactic correction of immunodeficiency conditions in agricultural animals // Perm Federal Research Center Journal. - 2021. - № 4. - P. 31-36. https://doi.org/10.7242/2658-705X/2021.4.3

The paper presents the results of feeding dairy cattle with vitamin-herbal flour from safflower leuzea, sandy sainfoin and meadow clover in order to improve metabolic processes in the body and reproductive function of cows. Zootechnical and veterinary sciences provide for the implementation and development of progressive modern technologies for the production of livestock products and raw materials. In line with the ongoing state policy of import substitution, the need of increasing the production food products, cow's milk and beef meat being of special importance. To ensure sustainable growth in the livestock and productivity of cattle, it is necessary to have healthy purebred young stock. In 2016-2020 in the Perm Region, at livestock farms of all categories non-infectious pathology of the digestive system was recorded in cattle in $42-44 \%$ of cases, including $76,7 \%$ of cases in young animals, based on the Form 2-vet data. The analysis of the incidence of respiratory diseases in cattle in the Perm Region showed that respiratory diseases of calves are widespread $(25-31 \%$ of the total number of patients with non-communicable diseases). This pathology is difficult at the age of transition to group keeping of animals. Despite the extensive arsenal of immunomodulators of natural and synthetic origin accumulated in recent decades, the question of finding the most active, environmentally friendly means remains relevant. Under conditions of modern dairy farming, the use of various feed additives, premixes, probiotic preparations, including dry plant raw materials as vitamin-herbal flour, has become widespread in animal feeding, providing a high level of productivity and reducing the cost of metabolic energy per unit of production and the safety of young animals. The research results can be used in the selection of perennial grasses, in the fields of seed growing and fodder production, when feeding animals in farms of any form of ownership.

Keywords: medicinal plants, biologically active substances, secondary immunodeficiencies, cattle, immunomodulators, veterinary phytopharmacology, agriculture.

\section{Сведения об авторах}

Жданова Ирина Николаевна, кандидат ветеринарных наук, старший научный сотрудник лаборатории биологически активных кормов, Пермский научно-исследовательский институт сельского хозяйства - филиал Пермского федерального исследовательского центра УрО РАН («Пермский НИИСХ»), 614532, Пермский край, Пермский район, с. Лобаново, ул. Культуры, 12; e-mail: saratov_perm@mail.ru

Суханова Елена Валерьевна, младший научный сотрудник лаборатории биологически активных кормов, «Пермский НИИСХ»; e-mail: elene831@mail.ru 